\title{
感潮域における底質からの鉄, マンガンおよび亜鉛の溶出 DESORPTION OF DISSOLVED IRON, MANGANESE AND ZINC FROM SEDIMENT IN AN ESTUARY
}

\author{
石橋融子 1 ・鳥羽峰樹 2 ・田中義人 3 ・熊谷博史 4 ・松尾宏 5 ・今任稔彦 6 \\ Yuko ISHIBSHI, Mineki TOBA, Yoshito TANAKA, Hiroshi KUMAGAI, Hiroshi MATSUO and \\ Toshihiko IMATO

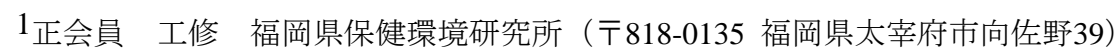 \\ 2非会員 理学 福岡県保健環境研究所（T818-0135 福岡県太宰府市向佐野39） \\ 3非会員 農博 福岡県保健環境研究所（T818-0135 福岡県太宰府市向佐野39） \\ 4正会員 工博 福岡県保健環境研究所（T818-0135 福岡県太宰府市向佐野39） \\ 5非会員 理学 福岡県保健環境研究所（T818-0135 福岡県太宰府市向佐野39） \\ 6非会員 工博 九州大学 工学研究院応用化学部門（下819-0395 福岡県福岡市西区元岡744番地）
}

\begin{abstract}
We surveyed suspended solids (SS) and heavy metal ions, such as iron, manganese and zinc in sediments, in order to evaluate contribution of sediments to heavy metal ions in the estuary. We found that SS increased in the estuary during low tide and this fact was concluded to be due to resuspension of sediments by a large tidal difference. The sediment samples were equilibrated with seawater at several concentrations, which were diluted with water. As a result, iron concentration dissolved into the mixed seawater was negligibly low. This may be due to the fact that iron exists as an iron complex with humic substances, which is insoluble into the mixed seawater by the salting-out effect. While, the concentrations of manganese and zinc dissolved into the seawater were found to increase with increase in salinity in the seawater, which was in good accordance with the results that the fractions of manganese and zinc in the exchangeable form in the sediment samples were higher than that in the other samples.
\end{abstract}

Key Words : Sediment, estuary, iron, manganese, zinc

\section{1. はじめに}

有明海はのり養殖が盛んで, また, タイラギなど貝類 も重要な水産資源となっている. しかし, 近年, 植物プ ランクトンの異常発生や貧酸素水塊などの問題が起こり, 様々な環境影響が懸念されている1). 有明海は閉鎖性海 域であることから，栄養塩を含め河川から流出する様々 な物質が海域生態系に影響を与える可能性がある.

溶解性鉄は，海域の植物プランクトンなど生物にとっ て重要な元素であり 2),3)，河川水中ではフミン物質などと 錯体を形成して海域へと流れ込むことから，河川は重要 な鉄供給源として考えられている3．一方，マンガンに ついては，有明海の底質に多く含まれるマンガンのアサ リ生息への影響が指摘され, 現在, 研究がなされている
ところである . 覀鉛（特に溶解性亜鉛）は，生物への 影響評価試験が数多く報告され，その影響が指摘されて いる5 . 溶解性鉄, マンガンおよび亜鉛の河川から海域 への輸送を把握することは, 現在盛んに行われている栄 養塩類の研究とあわせ，有明海を総合的に理解すること に役立つものと考えられる．溶解性鉄およびマンガンは 凝集作用, $\mathrm{pH}$ 変化, 微生物反応などによる沈降や溶 出6),7),8),9)，溶解性亜鉛は鉄やマンガンとの共沈 ${ }^{10), 11) な と ゙ ~}$ により，河川に含まれるこれら重金属類の濃度（輸送 量）は感潮域で変化し，陸域からそのまま海域へと流れ 込むことはない(12),13). 特に, 河川から海域への溶解性鉄, マンガンおよび亜鉛の輸送を把握するためには，感潮域 での挙動を把握することが必要となる．感潮域での水質

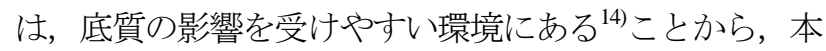
研究では，感潮域での鉄，マンガンおよび亚鉛の挙動を 
解明するための一つの手がかりとなるこれら重金属類の 底質からの溶出について検討したので報告する。

\section{2. 方法}

\section{（1）試料採取地点}

大牟田川は，有明海にそそぐ三面側溝の小規模都市河 川で, 河川に沿って立ち並ぶ事業場の排出水の影響を強 く受ける河川である. 試料採取地点を図-1 に示寸．河 川水の採取地点は，A〜F地点である. 感潮域は $\mathrm{A} \sim \mathrm{D}$ 地 点である，底質は，2010年4月に，泥干潟の広がるA地 点および三面側溝のC地点で採取した。また，大牟田川 河口に近い干潟のG地点（2010年4月）および海域のst.8

（2009年7月）でも採取した．有明海の採水は，湾奥北 東部の11地点（st.1〜11）で行った.

\section{（2）海水および河川水の採取と分析方法}

海水は2008年4月～2009年12月の間で毎月1回（全21 回），河川水は2008年4月～2009年12月の間で2ケ月に1 〜数回（全25回）採取した。表層はバケツ，底層はバン ドン採水器を用いて採水した．河川水の採水は，全て降 雨の影響のない日に行った.

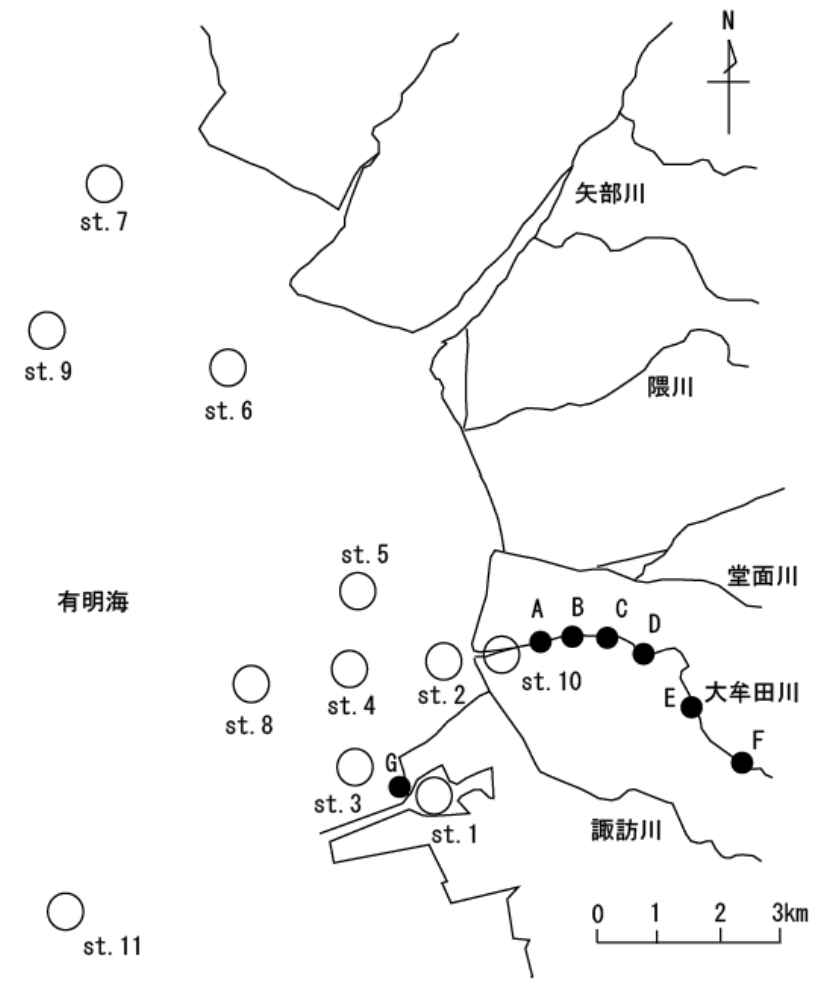

図-1 試料採取地点

ただし

: A Fは河川採取地点，A，CおよびGは底質採取地

点.

O : st. 1 11は海水採取地点, st. 8は底質採取地点.
浮遊物質（SS）は，ガラス繊維ろ紙（ADVANTEC GS-25, 孔径 $1 \mu \mathrm{m})$ でろ過したものの重量から求めた ${ }^{15}$. また，A地点において，酸化還元電位（Eh）は携帯用 ORP電極（TOA，RM-12P）を，溶存酸素（DO）はDO メーター（飯島，ID-100）を用い，2009年12月（冬季） および2010年8月（夏季）の2回, 満潮時の表層, 底層お よび干潮時に測定した.

\section{（3）底質の採取および分析方法}

底質は，スコップまたはひしゃくを用いて採取した。

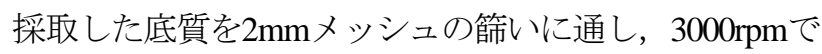
20分間遠心分離した後，上澄み液を捨て，残留物を湿試 料とした ${ }^{16)}$.

含水率は，湿試料を $105^{\circ} \mathrm{C}$ で乾燥させ（乾試料），蒸 発した水分の重さから求めた ${ }^{16)}$. 強熱減量（IL）は，乾 試料を $600^{\circ} \mathrm{C}$ で乾燥させ, 減少した重さから求めた ${ }^{16)}$.

全鉄，全マンガンおよび全亜鉛含有量（T-Fe，T-Mn およびT-Zn）は，硝酸および塩酸を加え $200^{\circ} \mathrm{C} て ゙$ 加熱し て有機物を分解した後, 万過（Whatman, 5B） ᄂ ${ }^{16)}$, ICP発光分析法（Varian, Vista-pro）で濃度を測定して ${ }^{15}$, 乾重量当たりの重量に換算して求めた.

\section{（4）底質の溶出試験方法}

感潮域での底質の巻き上げによる鉄，マンガンおよび 亜鉛の河川水一の溶出を検討するため，ミリQ水と海水 を数種の混合割合で調整したもの（試験水）を用いて， 溶出試験を行った. 海水は, st.10を除く全ての地点の表 層および底層（2010年3月採水）を同割合で混合し， $0.45 \mu \mathrm{m}$ メンブランフィルターでろ過したものを使用し た。海水の鉄濃度は $0.001 \mathrm{mg} /$ 以下, マンガン濃度は $0.003 \mathrm{mg} / \mathrm{l}$ ，亜鈆濃度は0.001mg/以下であった。底質は，

A，CおよびG地点で採取したものを使用した．各底質に 試験水を1:10の割合で加え，常に酸素が供給されるよう， 振とう器（IWAKI，KM Shaker）を用いて常温で1時間 振とうした後静置し, 上澄み液を $0.45 \mu \mathrm{m}$ メンブラン フィルターでろ過した。 ろ液の濃度をICP発光分析法ま たはICP-MS法（Agilent，7500ce）で測定し，乾重量当 たりの重量に換算して底質中の溶解性鉄，溶解性マンガ ンおよび溶解性亜鉛含有量（D-Fe，D-MnおよびD-Zn） を求めた ${ }^{17}$.

\section{（5）底質中重金属の分別定量方法 177, 18) 199，20)}

各底質の溶出試験結果の相違を検討寸るため, 水溶性 成分，交換性イオン成分（アンモニウムイオンと可換な 成分），炭酸塩（弱酸可溶成分），遊離酸化物（還元抽 出成分），有機物（酸抽出成分）および残渣釷物の6種 類に分画した. 方法をa) f ) に示す.

\section{a）水溶性成分：第 I 分画}

湿試料約 $2.5 \mathrm{~g}$ を50ml遠心管にとり，ミリQ水 $25 \mathrm{ml}$ 加 え，室温で1時間振とうした。 


\section{b）交換性イオン成分 : 第 II 分画}

a)の残渣に1M酢酸アンモニウム溶液を $20 \mathrm{ml}$ 加え，室 温で1時間振とうした。

c）炭酸塩（弱酸可溶成分）：第臬分画

b)の残渣に1M䣷酸アンモニウム酶酸溶液（pH5.0）を 20ml加え, 室温で1時間振とうした。

d）遊離酸化物（還元抽出成分）：第IV分画

c)の残渣に $0.04 \mathrm{M}$ 塩酸ヒドロキシルアミン $25 \%$ 酢酸溶 液を50mlを加え, $95^{\circ} \mathrm{C}$ で 6 時間加熱抽出した.

\section{e）有機物（酸化抽出成分）：第V分画}

d) の残渣に $0.02 \mathrm{M}$ 硝酸 $7.5 \mathrm{ml}$ おび $30 \%$ 過酸化水素水 $12.5 \mathrm{ml}$ 加え, 室温で1時間振とうし， $85^{\circ} \mathrm{C} て ゙ 2$ 時間加熱 抽出した. さらに，30\%過酸化水素水 $7.5 \mathrm{ml}$ 加えて2時 間加熱を続けた. 遠心分離後, 残渣に3.2M酰酸アンモニ ウム $20 \%$ 硝酸溶液を $12.5 \mathrm{ml}$ 加え, 室温で30分間振とうし た. 先の上澄み液とあわせ，第 $\mathrm{V}$ 分画の抽出液とした.

なお，a) e)の抽出液は3,500rpmで30分間遠心分離し， $25 \mathrm{ml}$ のリ Q 水で2回洗浄した. また, 抽出液は全て硝 酸を加えて加熱分解し, ICP発光分析法で測定した.

\section{f）残渣鉱物 : 第VI分画}

(3)で求めたT-Fe，T-MnおよびT-Znからa)〜e)の合計を 差し引いて求めた.

\section{3. 結果および考察}

\section{（1）感潮域における河川水のSS}

A地点での満潮時刻を 0 としたときの採水時間とSSと の関係を図-2 に示す．満潮のときSSは最も低く, 約 10mg/である. 海水 (st.1〜11) のSSも約10mg/であるこ とから，海水とほとんど変わらないことがわかった。一 方，干潮になるにつれ，SSが増大し，干潮前後で最大と なることがわかった．潮の影響のないEおよびF地点の SSは，ほとんどの検体で1mg/以下であったことから， SSの上昇は，上流からの供給が原因ではないと考えられ る. 有明海は干満の差が大きく, 特に, A地点では, 水 位は満潮では $4 \mathrm{~m}$ 以上あるものの, 干潮では, 数十 $\mathrm{cm} に$ までになる. 以上のことから, 潮の満ち引きによって, 底質の巻き上げが起こり，SSが増大したものと考えられ る.また，A地点におけるEhおよび DOの測定結果を 表-1 に示す. 干潮時にEhの低下が見られるが，これは， 還元的環境にある下層の底質の巻き上げによる影響と考 えられる。しかし，EhおよびDOの值から，A地点は常 に酸化的環境にあることがわかった，すなわち，干潮時 の底質の巻き上げによる溶出は, 酸化的環境で検討寸る 必要があると考えられる。

\section{（2）底質の性状}

底質の性状を表-2 に示寸. A地点は, 有機物, 水分

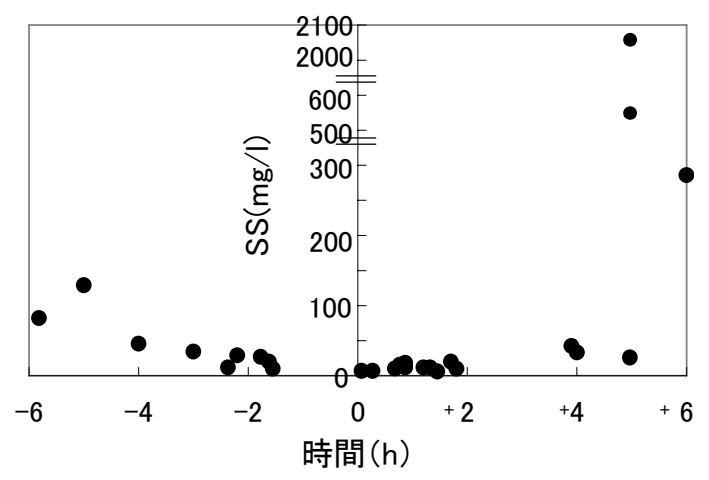

図-2 満潮からの時間とSSとの関係（A地点）

表-1 A地点におけるEhおよびDO

\begin{tabular}{|c|c|c|c|c|c|}
\hline \multicolumn{2}{|c|}{ 地点 } & \multicolumn{2}{|c|}{ 冬季 } & \multicolumn{2}{c|}{ 夏季 } \\
\cline { 3 - 6 } \multicolumn{2}{|c|}{} & $\mathrm{Eh}(\mathrm{mV})$ & $\mathrm{DO}(\mathrm{mg} / \mathrm{l})$ & $\mathrm{Eh}(\mathrm{mV})$ & $\mathrm{DO}(\mathrm{mg} / \mathrm{l})$ \\
\hline 満潮 & 表層 & 407 & 7.3 & 325 & 4.6 \\
\hline & 底層 & 375 & 9.4 & 302 & 4.5 \\
\hline 干潮 & & 178 & 9.8 & 265 & 4.7 \\
\cline { 2 - 6 } & & &
\end{tabular}

表-2 底質の性状

\begin{tabular}{|c|c|c|c|c|c|}
\hline 地点 & $\begin{array}{c}\text { 含水率 } \\
\text { (\%) }\end{array}$ & $\mathrm{IL}(\%)$ & \multicolumn{3}{|c|}{ 含有量 $(\mu \mathrm{g} / \mathrm{g})$} \\
\cline { 4 - 6 } & & $\mathrm{T}-\mathrm{Fe}(\mathrm{S})$ & $\mathrm{T}-\mathrm{Mn}(\mathrm{S})$ & $\mathrm{T}-\mathrm{Zn}(\mathrm{S})$ \\
\hline \hline A & 58.3 & 11.7 & 36,500 & 635 & 460 \\
\hline C & 21.3 & 2.41 & 25,500 & 492 & 384 \\
\hline G & 25.6 & 3.05 & 24,300 & 2,120 & 87.0 \\
\hline St.8 & 33.6 & 6.12 & 28,700 & 1,940 & 107 \\
\hline
\end{tabular}

を多く含む底質であった，その他の地点は，砂質であっ た. T-FeはA地点が最も高く, 次いで, st.8が高い值で あった．鉛などの重金属類の含有量は，ILや含水率と相 関関係があると報告されている21,222．T-Feについても同 様に，Iおよび含水率の高いA地点およびst.8が高い值で あったと考えられる、T-Mnは，G地点が最も高かった。 有明海のT-Mnは，227～1,912（平均值786） $\mu \mathrm{g} / \mathrm{g}$ と報告 がなされている23)。また， st.8の底質を測定したところ， $1,940 \mu \mathrm{g} / \mathrm{g}$ で高い值であったが，G地点は，これらの結 果よりさらに高く, 2,120 $\mu \mathrm{g} / \mathrm{g}$ であった. しかし, 本調 查対象区域より南側に位置する熊本県荒尾市でT-Mnが $1,700 \sim 2,900 \mu \mathrm{g} / \mathrm{g}$ 検出されている4)ことから,G地点でTMnが高かった原因については，河川による陸域からの 負荷によるものではなく, 別の要因が関与していると考 えられるため, 今後, 別途検討寸る必要がある. 都市河 川底質（感潮域および非感潮域含む）のT-Mnは，295〜 $1,150 \mu \mathrm{g} / \mathrm{g}$ との報告があり ${ }^{20,24)}$, A地点およびC地点のTMnはこの範囲内にあった. T-Znは, A地点, C地点の順 で高く, G地点が最も低かった. 都市河川底質（感潮域 および非感潮域含む）のT-Znは，59～2,780 $\mu \mathrm{g} / \mathrm{g}$ との報 告がある ${ }^{20), 24)}$. 今回，測定した底質は全てこの範囲内に あったが，文献でT-Znが高い值を示した底質については， 鉱山や事業場排水の影響により高い值であったと推測し 

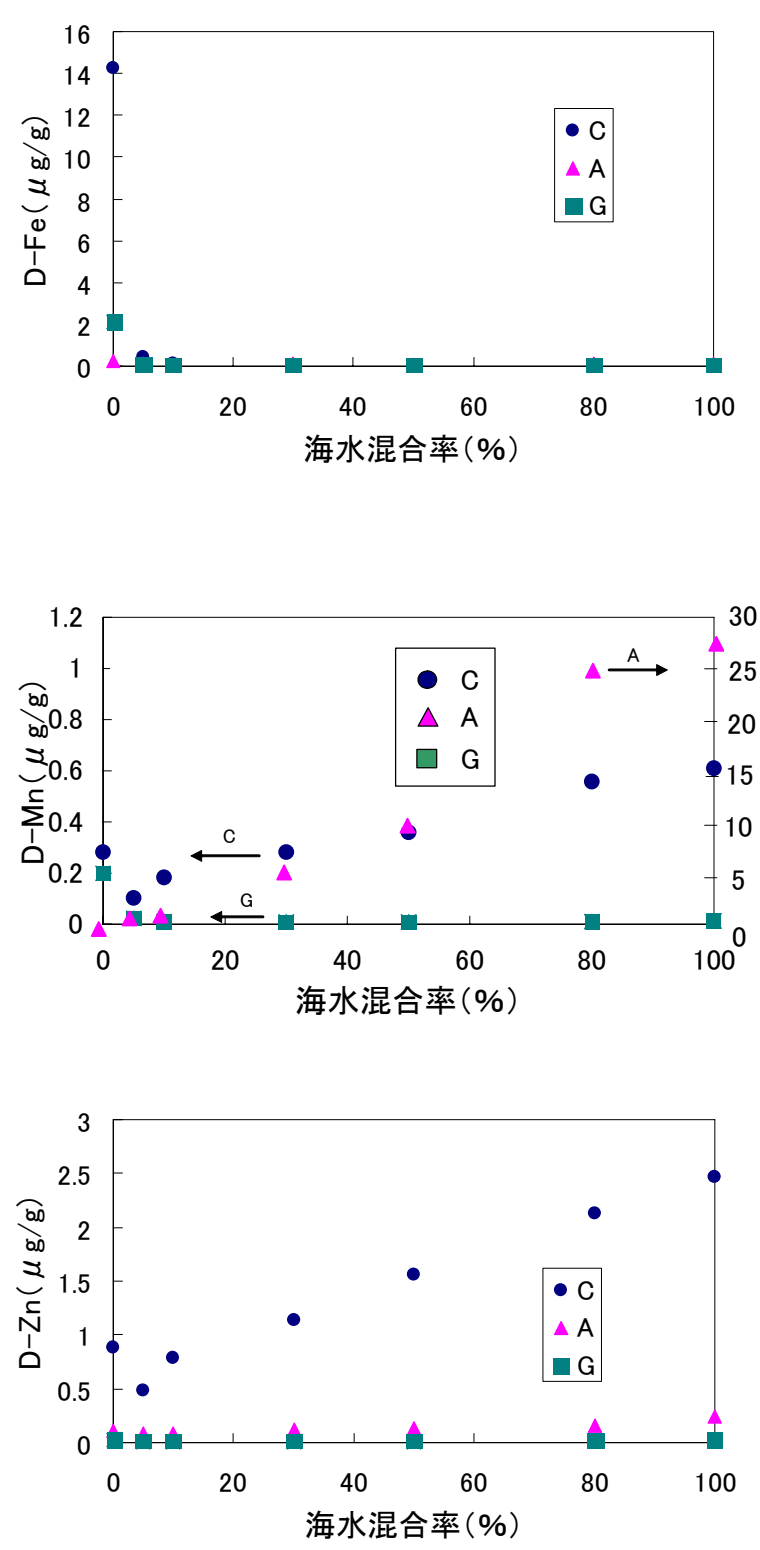

図-3 D-Fe，D-MnおよびD-Znと試験水の海水混合率との関係

ている20,24)，そこで，福岡県内で事業場排水の影響の少 ない他の河川感潮域の底質5検体のT-Znを測定したとこ ろ，19.2～315 $\mu \mathrm{g} / \mathrm{g}$ (IL: 0.7〜 11.3\%）であり，A地点お よびC地点ともこれらの結果より高い值であった.これ は，A地点およびC地点のすぐ近くには，事業場の排水 口があり，その排水には多くの亜鉛が含まれている.こ の亜鉛がA地点およびC地点で沈降し，T-Znが高くなっ たと考えられる.

\section{（3）底質からの溶出}

D-Fe，D-MnおよびD-Zn と試験水の海水混合率との関 係を図-3 に，底質の分別定量分析結果を図-4 に示す.

\section{a) 鉄}

図-3 より，全ての検体について，海水が混入するこ とによって，D-Feの低下が見られた. 図-4 より，底質
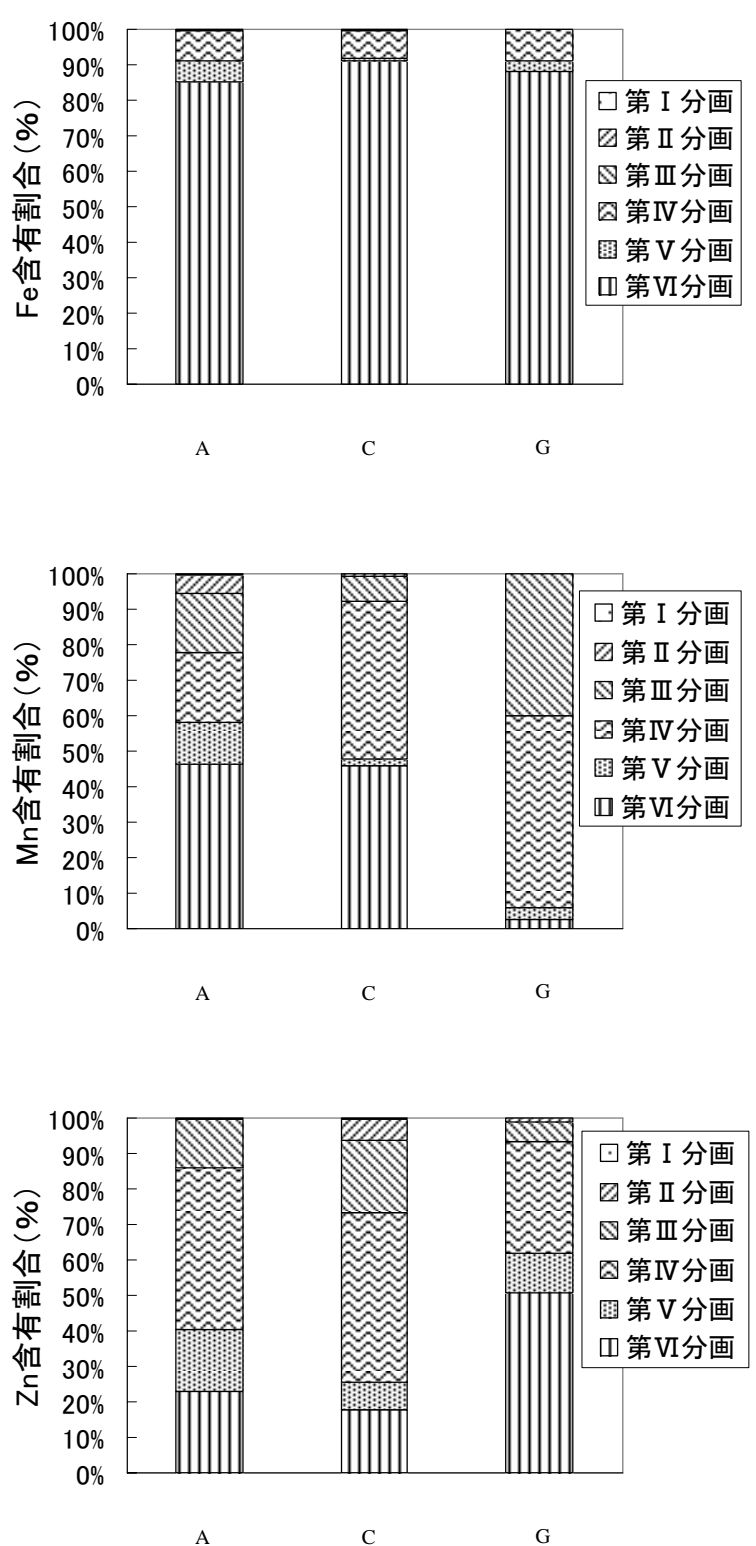

図-4 各分画毎のFe，MnおよびZn含有割合

中の鉄は，ほとんどが鉱物由来であり，第 $\mathrm{I} \sim \mathrm{V}$ 分画で 抽出される鉄の割合は低かった．海水混合率0\%で溶出 したのは，わずかに含まれる水溶性成分（第 I 分画）で あったと考えられる. 鉄は, 河川水中でフミン物質など と錯体を形成した状態で溶解しているが，フミン物質な どは多量の塩により塩析することが知られており ${ }^{25)}$, 感 潮域で沈殿するものと考えられる。今回，底質に含まれ る鉄についても，底質から溶解した鉄錯体が海水の混入 により沈殿したものと考えられる. なお，調査地点は， 干潮時でも電気伝導率（EC） は $1,000 \mu \mathrm{S} / \mathrm{cm}$ 以上あるこ とから，潮の影響が残る地点である.よって，底質から の鉄の溶出はないものと考えられる.

b) マンガン

図-3 より，A地点およびC地点は，海水混合率が上昇 するにつれ，D-Mnが増加した．特に，A地点のD-Mnの 
上昇が見られ，海水により底質からのMn溶出量が増加 することがわかった。一方，G地点は，海水混合率が上 昇するにつれD-Mnは低下した。 マンガンは鉄と同様に フミン物質などと錯体を形成することが知られているが， その割合は鉄と比較してわずかである ${ }^{26}$ ため，鉄とは異 なる結果が得られたと考えられる．A地点でD-Mnが他 の地点と比較して高い值で，また，海水の割合が増加す るに伴い増加した．これは，図-4 より，第II分画のMn 含有割合が5.46\%で，C地点（0.48\%）およびG地点 (0.018\%) と比較して大きいため, 海水に含まれる高濃 度の塩により第 II 分画のMnがイオン交換される割合が 多かったためと考えられる. また，A地点の第II分画の $\mathrm{Mn}$ 含有量は, $34.7 \mu \mathrm{g} / \mathrm{g}$ であり, 試験水の海水混合率が

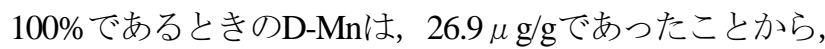
第 II分画のMnの一部がイオン交換され，Mnが溶出した と考えられる.

\section{c) 亜鉛}

図-3 より，A地点およびG地点では，Znはほとんど溶 出しなかったが, C地点は, 海水混合率が上昇するにつ れD-Znが増加した．第II分画のZn含有割合は，C地点が 5.93\%で最も多く，AおよびG地点では，0.37\%および 0.89\%でほとんど含まれていなかった．C地点で，D-Zn が他の地点と比較して高い值で，また，海水の割合が増 加するに伴い増加したのは, Mnと同様に, 第II分画の Znがイオン交換され溶出したためであると考えられる. また，C地点の第II分画のZn含有量は，22.8 $\mu \mathrm{g} / \mathrm{g} て ゙ ，$ 試 験水の海水混合率が100\%のときのD-Znは2.46 $\mu \mathrm{g} / \mathrm{g}$ で あったことから，第II分画のZnの一部がイオン交換され， Znが溶出したものと考えられる.

\section{4. まとめ}

感潮域における干潮時での底質からの鉄，マンガンお よび覀鉛の溶出を検討するため, 底質の溶出試験を行っ た. その結果，底質からの鉄の溶出はないことがわかっ た. マンガンについては，第I分画で抽出される形態の ものが多く含まれるA地点で, 亜鉛については, C地点 で，底質から試験水一の溶出量が多く，海水の混合割合 が増加するに伴い，第II分画で抽出されたマンガンまた は亜鉛の一部がイオン交換され，溶出量が増加寸ること がわかった。

謝辞 : 本研究は，鉄鋼環境基金研究助成により実施され た.

\section{参考文献}

1) 有明海・八代海総合調查評価委員会: 委員会報告, 環境省, 2006.

2) 藤永太一郎: 海と湖の化学, 京都大学学術出版会, pp.237-
245, 2005.

3) Kuma, K., Tanaka, J., Matsunaga, K. and Matsunaga K.: Effect of hydroxamate ferrisiderophore comples (ferrichrome) on iron uptake and growth of a coastal marine diatom, Chaetoceros sociale, Limnology and Oceanography, Vol.45(6), pp.1235-1244, 2000.

4) Tsutsumi, H., Tsukuda, M., Yoshioka, M., Koga, M., Shinohara, R., Nomura, Y., Choi, K., Cho, H. and Hong, J.: Heavy metal contamination in the sediment and its effect on the occurrence of the most dominant bivalve, Ruditapes philippinarum, on the tidal flats of Ariake Bay in Kumamoto prefecture, the west coast of Kyushu, Japan, Benthos Research, Vol.58(2), pp.121-130, 2003.

5）独立行政法人製品評価技術基盤機構, 財団法人化学物質評 価研究機構 : 亜鉛の水溶性化合物 Zinc compounds (watersoluble) 化学物質排出把握管理促進法政令号番号 : 1-1, 化 学物質の初期リスク評価書, 1(131), pp.26-38, 2008.

6) Eckert, J. M. and Sholkovitz, E. R.: The flocculation of iron, aluminium and jumates from river water by electrolytes, Geocimica et Cosmochimica Acta, Vol.40, pp.847-848, 1976.

7) Edward, R. and Sholkovitz: The flocculation of dissolved Fe, Mn, $\mathrm{Al}, \mathrm{Cu}, \mathrm{Ni}, \mathrm{Co}$ and $\mathrm{Cd}$ during estuarine mixing, Earth and Planetary Science Letters, Vol.41, pp77-86, 1978.

8) Boughriet, A., Ouddane, B., Fischer, J. C., Wartel, M. and Leman, G.: Variability of dissolved $\mathrm{Mn}$ and $\mathrm{Zn}$ in the seine estuary and chemical speciation of these metals in suspended matter, Water Research, Vol.26(10), pp.1359-1378, 1992.

9) Teraoka, H. and Ogawa, M.: Behavior of trace elements in the Takahashi River estuary, Japan, Japanese journal of limnology, Vol.45(1), pp.6-12, 1984.

10) 藤永太一郎: 海と湖の化学, 京都大学学術出版会, pp.397412, 2005.

11) 田村紘基, 笹木邦道, 中井通, 片山則昭, 永山政一: 二酸 化マンガンに対する亜鉛イオンの吸着平衡, 分析化学, Vol.35, pp.966-971, 1986.

12) Salomon, W. and Forstner, U.: Metals in estuaries and coastal environments, Metals in the Hydrocycle, Springer-Verlag, Berlin, pp.212-257, 1984.

13) Jouanneau, M. J. and Latouche, C.: Estimation of fluxes to the ocean from mega-tidal estuaries under moderate climates and the problems they present, Hydrobiologia, Vol.91, pp.23-29, 1982.

14) 楠田哲也, 山本晃一: 河川汽水域, 技報堂出版株式会社, pp.131-157, 2008.

15) 島弘志: JIS K 0102 工場排水試験方法，財団法人日本規格 協会, 2008.

16) 環境庁水質保全局水質管理課: 底質試験方法とその解説, 丸善株式会社, 1985.

17) Ishibashi, Y. Matsuo, H., Baba, Y., Nagafuchi, Y., Imato, T. and Hirata, T.: Association of manganese effluent with the application of fertilizer and manure on tea field, Water Research, Vol.38, pp.2821-2826, 2004.

18) 不破敬一郎: 環境試料中の無機元素の存在形態分析による 
環境変化の解析，環境試料の保存とそれを用いた環境変化 の解析法に関する研究（I），「環境科学」研究報告集， 文部省「環境科学」特別研究 “試料保存” 研究班, pp.1-16, 1983.

19) 芦田賢一，駒井幸雄: 河川底質中重金属の分別定量, 兵庫 県公害研究所研究報告第16号, pp.50-54, 1984.

20) 白柳康夫: 底質における金属類の粒度分布および存在形態, 横浜市郊外研究所報第9号, pp.161-167, 1984.

21) 駒井幸雄, 竹田洋子, 梅本諭: 兵庫県における河川底質重 金属濃度の長期変動傾向とその評価，兵庫県立健康環境科 学研究センター紀要, Vol.2, pp.72-80, 2005.

22) Watanabe, N., Yasuda, Y., Kato, K., Nakamura, T., Shimokawa, K. and Ose, Y.: Evaluation of extraction techniques for the determination of heaby metals in river sediments, Japanese
Journal of limnology, Vol.44(2), pp.123-131, 1983.

23) 門上希和夫，伊豫岡宏樹，上田直子，濱田健一郎，陣矢大 助，岩村幸美，楠田哲也: 閉鎖性 2 海域（洞海湾，有明海） における底質中の有害物質蓄積量, 用水と廃水, Vol.51(12), pp.47-56, 2009.

24) 芦田賢一: 河川底質中重金属の分別定量（第2報），兵庫県 立公害研究所研究報告第19号, pp.111-115, 1987.

25) 金子行裕, 河原田裕, 安居院渡, 安陪正彦, 荻野圭三: 水 中に溶存するフミン質の吸着除去（第3報）フミン質の吸着 特性に及ぼす塩析効果, 油化学Vol.37(7), pp.531-534, 1988.

26) Kerndorff, H. and Schnitzer, M.: Sorption of metals on humic acid, Geochimica et Cosmochimica Acta, Vol.44, pp.1701-1708, 1980.

(2010. 9. 30受付) 